\title{
Coming to Terms with Environmental Justice in Outdoor Recreation: A Conceptual Discussion with Research Implications
}

\author{
MYRON F. FLOYD \\ Center for Tourism Research and Development \\ Department of Recreation, Parks and Tourism \\ University of Florida \\ Gainesville, Florida, USA
}

CASSANDRA Y. JOHNSON

Southern Research Station

USDA Forest Service

Athens, Georgia, USA

\begin{abstract}
Much the research on environmental justice centers on environmental hazards. This article offers an overview of the emergence of environmental justice issues in outdoor recreation management and research. The authors argue that a major challenge to future research on environmental justice in outdoor recreation is clarifying definitions of environmental justice and generating awareness of the different dimensions of environmental justice. The authors also examine recent empirical studies of environmental justice issues related to outdoor recreation and other resource amenities. Based on an overview of the literature and these recent studies, the authors set forth some broad outlines to guide future research.
\end{abstract}

Keywords environmental justice, equity, environmental racism, outdoor recreation, tourism development, policy

"Let justice roll down like waters and righteousness like an ever flowing stream."

(Amos, Chapter 5 Verse 24, Revised Standard Version of the Holy Bible)

The rise of the environmental justice movement in the 1980s spawned a flurry of research activity, initiated new forms of environmental rules and regulations, and introduced alternative strategies and tactics to mainstream environmental activism. At the center of this activity was growing recognition and awareness of unevenness in the distribution of environmental costs and benefits. Claims of environmental injustice, whereby people of color and low-income communities suffer disproportionate exposure to environmental hazards, were asserted. Social scientists from a variety of disciplinary perspectives have provided both conceptual analysis and empirical evidence to substantiate such claims.

Received 15 February 2001 ; accepted 6 October 2001.

Research for this article was supported by the Southern Research Station (SRS-4901). United States Department of Agriculture, Forest Service. The authors wish to acknowledge the support of Ken Cordell for making this collaboration possible. Opinions expressed should be attributed to the authors solely.

Address correspondence to Myron Floyd, Center for Tourism Research and Development, Department of Recreation, Parks, and Tourism, PO. Box $\mid$ 18209, University of Florida, Gainesville, FL 326 1-8209. E-mail: mfloyd@hhp.ufl.edu 
Until the issuance of Executive Order 12898 in 1994, recreation management and tourism development within federal land management agencies seemingly existed outside the purview of environmental justice. Federal land management agencies (and all federal agencies) are now directed to develop agency-wide environmental justice strategies and to "identify differential patterns of consumption of natural resources among minority populations and low-income populations" (Executive Order No. 12898, 1994). Moreover, each agency is directed to ensure that its programs and policies are initiated in a manner that does not exclude individuals or groups from receiving benefits or subject individuals or populations to discriminatory practices due to race, ethnicity, or national origin. The executive order further directs federal agencies to collect, maintain, and analyze information on consumption patterns of populations dependent upon fish, wildlife, or both for subsistence. Agencies have the responsibility for communicating to the public risks associated with their consumption patterns. Finally, the agencies must ensure communications related to health risks and environmental impacts are "concise, understandable, and readily accessible to the public" (Executive Order 12898, 1994).

Management of natural resources for recreation and tourism produces numerous social and economic benefits (Driver, Brown, \& Peterson, 1991) and often generates significant positive and negative impacts on the natural environment and local economies (Gramann, 1996). Consequently, questions of how the costs and benefits associated with recreation and tourism development are distributed by race, ethnicity, and income, and what accounts for a particular pattern of distribution can be framed by an environmental justice perspective.

There has been only limited inquiry into what environmental justice means in the context of recreation, and how it should (or might) alter policy and management activities is unclear. To date, research related to race, ethnicity, and socioeconomic status in the outdoor recreation literature has been limited to how minority status impacts visitation to national parks, forests and wilderness (Floyd, 1999; Johnson, Bowker. \& Cordell, in press; Johnson, Horan, \& Pepper, 1997; Washbume, 1978). To explain divergent patterns of natural resource recreation use between Whites and people of color, researchers working in this area have employed concepts such as marginality (e.g., Washbume, 1978), interpersonal and institutional discrimination (Floyd, Gramann, \&.Saenz, 1993; West, 1989) and structural constraints (Johnson, Bowker, English, \& Worthen, 1998). Such concepts reflect concerns about equity and equality of access, but where they fit into the recent emphasis on environmental justice remains unexplored.

This state of affairs is not surprising as most environmental justice activities (e.g., activism, research, and policy making) center on the uneven distribution of environmental hazards, health risks, and locally undesirable land uses. Only recently have social scientists directed their attention to outdoor recreation and resource amenities (e.g., Aldy, Kramer, \& Holmes, 1999; Tar-rant \& Cordell, 1999; Whitehead, 2000). Because of directives inherent in E.O. 12898, additional analyses and consideration of how planning and service delivery associated with recreation management and tourism impact people of color and low-income populations (communities) will be required. Aside from satisfying policy mandates, an improved understanding of what leads to disparate negative impacts on people of color and low-income communities in the context of recreation management results in better delivery of services and benefits, and ultimately improved quality of life.

We review various definitions and dimensions of environmental justice with a view toward clarifying what it means in the context of outdoor recreation research and public lands management. Our review is divided into four sections. First, we examine how environmental justice has been defined in the literature. This section provides insight into the underpinnings of alternative definitions and elements of environmental justice. Next, we briefly review the origins of the environmental justice movement and note reasons for the current emphasis 
on environmental justice by federal recreation agencies. Following this, we assess the state of the literature on environmental justice in relation to outdoor recreation concerns. Finally, based on our review of the literature, we offer broad outlines of research needs for better understanding the nexus between environmental justice and outdoor recreation.

The term environmental justice encompasses a number of interrelated concepts and perspectives. While embodying a social movement, it functions as a claims-making activity or as an interpretive frame, constitutes a body of knowledge and research agenda, and represents an ideal and desired condition of life quality. As a social movement, environmental justice represents a fusion of the rhetoric and tactics of the U.S. civil rights movement and traditional environmental activism through which claims of environmental injustice and racism are articulated and asserted (Di Chiro, 1992; Szasz \& Meuser, 1997). Over time, the movement has broadened to include such issues as human rights, income inequalities, housing quality, homelessness, access to health care, transportation issues, redevelopment of brownfields, occupational safety and health, and sustainable development in domestic and international contexts in addition to exposure to pollution and toxic hazards (Goldman, 1996; Hofrichter, 1993).

As claims-making activity, environmental justice can be understood as an interpretive frame (Capek, 1993). From this perspective, the fusion of 1960s civil rights rhetoric and tactics with mainstream environmentalism constitutes an interpretative master frame linking racism, class inequality, social justice, and environmentalism within a single frame signifying meaning for the broader environmental movement (McGurty, 2000; Taylor, 2000). As a master frame, environmental justice provides the context for diagnosing environmental problems, attributing blame, and constructing solutions for achievement of just and equitable outcomes (McGurty, 2000). In other words, environmental justice as a claimsmaking activity can be viewed as socially constructed, particularly at the community and grassroots level (Capek, 1993; Perrolle, 1993). In this way the environmental justice movement has appropriated its own definition of environment and environmental problems, in essence reinventing while engaging innovative political discourses, practices and tactics (Di Chiro, 1996). Hence, a shift occurred in the "dominant environmental protection paradigm" (Bullard, 1994a) toward a paradigm that seeks to protect not only endangered species and wilderness but also vulnerable and endangered human communities, particularly the poor and people of color. Because of the broader interpretation of environmental justice, community spaces, outdoor recreation, leisure, and tourism activities should also be examined from an environmental justice perspective.

As a condition or state of being, environmental justice has been defined as "cultural norms and values, rules, regulations, behaviors, policies, and decisions to support sustainable communities, where people can interact with confidence that their environment is safe, nurturing, and productive" (Bryant, 1995, p. 6). This represents the fulfillment of the goals of the environmental justice movement where access to a clean and safe environment is a protected entitlement and fundamental civil right for all individuals and groups.

\section{Elements of Environmental Justice}

An immediate challenge to analyzing environmental justice issues in recreation management and research is the lack of definitional clarity with respect to environmental justice and related terms such as environmental equity and environmental racism. How the first term is defined conceptually and deployed in empirical studies has important implications for documenting relationships among race, poverty, and environmental problems and benefits and in the remediation of environmental problems (Clark, Lab, \& Stoddard, 1995; Downey, 1998). At this point, we discuss some of the most common terms used in environmental 
justice discourse with a review of the literature. Terms discussed are procedural, distributive, and corrective justice'; environmental equity; and environmental racism.

Procedural and distributive justice. Bullard (1994b) identified three types of equity that are prerequisites for the creation and maintenance of environmental justice-procedural, geographic, and social. ${ }^{2}$ Procedural equity has to do with fair practices in the application, enforcement, and implementation of laws and regulations regarding environmental toxins. This type of equity assumes environmental legislation will be applied to different societal groups in a way that does not place undue burdens on any one group. Bullard cites a number of procedural inequities, such as higher monetary penalties imposed for hazards adjacent to areas with mostly white populations than for areas with predominantly minority populations, These findings suggest that procedural justice is not extended to minority or other peripheral groups.

Geographic or distributive equity involves the equitable placement of hazardous waste facilities and other potentially threatening environmental resources across communities and neighborhoods, irrespective of racial makeup, socioeconomic level of residents, or housing values. Bullard (1994b), again, argues that people of color and the poor are more likely than others to live closer to such hazards.

Lake (1996) also addresses distributive and procedural equity but focuses more specifically on issues involving procedural rather than distributive justice. Lake argued that for environmental justice to be achieved, advocates must have as an ultimate goal procedural justice, which involves more than participation in decisions about where to locate environmental toxins (distributive justice) after they have been produced but also includes involvement by affected citizenry in decisions about the actual production of environmental goods and "bads." As commonly understood, procedural justice involves decisions about how environmental burdens will be distributed, or what procedures will be applied to achieve distributive justice given an existing number of environmental problems. Lake (1996) criticized this concept of procedural justice because it "accepts prior decisions as given and fails to extend the reach of equity and participation sufficiently deeply into the decision-making process (p. 164)."

According to Lake, the primary emphasis in environmental equity debates has been the locating of dangerous facilities, however, energy expended in equitably distributing toxins across a given area remains mired in the symptoms of greater social inequities. These efforts produce only cosmetic cures. Again, the greater environmental inequities have to do with unfair representation of the poor and minorities in decisions about not only where to locate facilities but also in decisions about the nature and quantity of environmental poisons. If the environmental justice movement is to go beyond the surface of social inequities, it must necessarily place vulnerable people in decision-making positions about production and not limit affected persons' participation to decisions about distribution.

Warren (1999) also finds fault with traditional distributive models that underpin environmental justice debates, and she analyzes these models in terms of ecofeminist theory. She draws from the philosophy of Young $(1990)^{3}$ to argue that nondistributive models, or those which are not blindly concerned with traditional notions of fairness, justice, and equity to individuals may actually provide a better frame for considering environmental justice than distributive models. Borrowing from Young, Warren writes that nondistributive models recognize the social decision-making structures of power and privilege that undergird distribution patterns. A nondistributive model would acknowledge a group's culture and have as its goal the preservation of traditional people's land ethics and cultural world views.

Warren proposed eight features of a nondistributive model of environmental justice. One feature is the idea that individuals are both social and ecological selves (i.e., the ecological is just as important as the social in definitions of who we are). Additional features are that 
seemingly nontangible resources such as concern for others constitute justice; and that justice cannot be readily defined as it exists in many forms.

Corrective justice. Corrective justice has to do with processes involved in rectifying instances of environmental injustice. There has been scant theorizing about corrective equity in terms of environmental justice. Taylor (2000) mentioned that, since its inception, the environmental justice movement has been concerned with distributive and corrective justice, the latter having ameliorative actions in the present or future to address past wrongs. However, corrective justice is always implied in situations where environmental injustice is discovered. For instance, Congress established the Superfund Act in 1980 which required the Environmental Protection Agency (EPA) to formulate policies and procedures for cleaning up toxins and hazardous waste that threaten public safety.

Environmental equity. A number of researchers have examined the question of whether race or class is the better predictor of environmental injustice; that is, whether environmental injustice results from racism or economic inequity (Bullard \& Wright, 1992; Downey, 1998; Mohai \& Bryant, 1992). Environmental racism is couched in terms of racial discrimination (discussed below), whether intentional or not. Alternatively, environmental equity references inequalities in class and income structures rather than race per se. Though income and race may interact, the primary thesis of environmental equity is that persons most likely to live in areas adjacent to environmental hazards are individuals and groups who do not possess the economic means to locate to more environmentally desirable areas. Thus, efforts to bring about environmental justice should focus on reducing income and class distinctions rather than attempting to eliminate racism.

Environmental racism. The term environmental racism became popular in the early 1990s following the Michigan Conference on Race and the Incidence of Environmental Hazards (Mohai \& Bryant, 1992; Taylor, 2000). According to Taylor, environmental racism was a more confrontational term that forged connections between racism and environmental policy. The term also better enabled activists to extend Civil Rights activities of prior decades to present issues regarding the environment.

Taylor (2000) provided a definition of environmental racism which emphasizes the discriminatory impact of environmental decisions, actions, and policies. According to Taylor, three issues interact to effect environmental racism: (a) prejudiced belief and behavior, (b) individual and institutional power to enforce prejudicial policies and behavior, and (c) privilege. There is also a list of scenarios that fall under the purview of environmental racism, including housing segregation and inaccessibility to quality environmental amenities such as outdoor parks and play areas.

Environmental racism has become virtually synonymous with environmental justice although some researchers challenge claims of the former (e.g., Blais, 1996; Clark et al., 199.3. More recent charges of environmental racism are articulated by African-American residents in Satterfield's (2000) study who accuse both the EPA and officials from a polluting chemical plant of environmental racism. Her respondents believed the EPA and plant officials knowingly withheld pertinent information about the plant's contamination range because the affected parties were African-American. They claim that White residents exposed to contaminants were notified of the dangers earlier than African-Americans, and the former were able to sell their properties earlier and more quickly. Satterfield remarks that affected parties in environmental justice disputes are typically those already marginalized by either racial and or class biases: “... contamination events often involve the stigmatization of the already stigmatized. Exposure to environmental hazards is not random but rather selective of socially and economically vulnerable populations" (p. 7). 
Pulido (1996) presents a critical argument of racism research generally and environmental racism in particular by taking issue with three primary assumptions of the nature of racism: (a) that racism is an identifiable, discrete entity that can be isolated from other forms of inequity; (b) that agreement exists as to what racism is, and that it is not a pervasive ideology; and (c) racism is fixed and unitary for all societal groups. Pulido's criticisms are relevant to the present discussion in that they'challenge the idea that environmental racism is intentional. For instance, Bryant (1995, p. 5) defines environmental racism as: “...those institutional rules, regulations, and policies or government or corporate decisions that deliberately target certain communities for least desirable land uses, resulting in the disproportionate exposure of toxic and hazardous waste on communities based upon certain prescribed biological characteristics."

In contrast, Pulido (1996) argues that environmental racism may be unintentional in that an entity may not make a conscious decision to discriminate; however, because the U.S.'s political, economic structure is predicated upon racist ideologies, racism is pervasive in the social structure-for instance, in the educational system, housing, and labor markets. Thus, environmental racism cannot be effectively isolated as a separate and identifiable form of racism whose effects can be neatly eradicated without considering how racism in other spheres of social life contribute to a given instance of environmental racism.

Similar to others whom Pulido (1996) criticizes, McGurty (2000) also assumes that environmental racism can be isolated from and is distinct from other forms of racism. In describing the sequence of events in Warren County, North Carolina, that lead to the environmental justice movement, McGurty says that original county concerns of possible groundwater contamination and a poor economy were eclipsed by charges of environmental racism when Black social justice advocates joined the campaign against the siting of a hazardous landfill in their county. In this case, Pulido would argue that the racism charged is not just contained in the siting decision (i.e., whether the county was selected because it was majority Black), but the poor economy exists in this area with a high Black concentration because of other structural factors that work to limit economic opportunities for Blacks and other people of color. The interconnectedness of different manifestations of racism should be considered in this situation.

Environmental equity (justice) or racism? Downey (1998) views as moot, polemical debates of whether race or class is the better explicator of environmental decision-making. $\mathrm{He}$ argues that to position race and class as competing explicators of environmental injustice is to create false distinctions between the two factors. To treat them as orthogonal is to isolate them from the larger fabric of inequality of which they form an integral part:

... race and income should not be theorized as competing explanatory variables.. . such an approach decontextualizes race and income by forcing researchers to abstract them from social, political, and historical processes involved in the formation of environmental hazard decisions. Rather than thinking of race and income as competing with one another, our understanding of environmental discrimination would be better served by conceptualizing race and income as interdependent factors. (p. 767)

\section{Emergence of Environmental Justice}

Why has environmental justice become a higher priority on the public land management agenda? The prominence of environmental justice in natural resources management generally, and its increasing relevance to outdoor recreation and tourism specifically, can be explained in part by several interrelated events. First, an accumulation of sociological and 
epidemiological research linked public policy decisions and exposure to environmental hazards to power differentials reflected in status characteristics such as residence, race, and class (Albrecht, 1995). For instance, studies have documented: the exposure of rural communities in Nevada to significant levels of radiation following open air nuclear testing, and subsequent nondisclosure of the associated risks; exposure of poor and minority workers to occupational environmental hazards, such as "brown lung disease" in textile plants; "black lung disease" in coal mining regions; and exposure of Navajo uranium mine workers to the threat of "radiogenic lung cancers" (Dawson, 1992; Wright, 1992). The accumulation of data from these and other situations began to fit together as a pattern of inequity in the treatment of poor and minority individuals.

Another in 1982 was the choice of Afton in Warren County, North Carolina, for a landfill site for 32,000 cubic yards of soil contaminated with polychlorinated biphenyl (PCB) (Bullard, 1990). Many consider this event as the flashpoint in the emergence of the environmental justice movement. Rural, predominantly African-American, and located in one of the poorest counties in the state, the community of Afton mounted vigorous opposition to the siting decision. Initially, the protests involved a coalition of local White landowners with little protest experience. When their efforts failed to effect changes in the siting decision, they enlisted the aid of veteran African-American civil rights leaders with experience in "disruptive direct action" (McGurty, 2000, p. 376). The protests grew from local mobilization efforts to include nationally-known civil rights leaders and social justice advocates. With the arrest of more than 500 demonstrators, the siting decision and subsequent protests attracted national attention (Bullard \& Wright, 1992; Szasz \& Meuser, 1997). Although the landfill decision was not overturned, a critical moment had been reached in environmental discourse. For the first time "African Americans had mobilized a national broad-based group to oppose what they defined as environmental racism (italics added)" (Bullard, 1994a, pp. 5-6).

Precipitated by the outcome at Warren County, two important empirical studies further propelled environmental justice onto the national environmental policy stage. First, an initial study by the U.S. General Accounting Office (GAO) following the events in Warren County came at the requests of Walter Fountroy, then Washington, D.C. representative to Congress, Jim Florio (D-NJ), and Al Gore (then representative from Tennessee). Focusing on the eight southeastern states comprising EPA Region IV, the U.S. GAO (1983) determined that three of the four communities containing large commercial hazardous waste landfills were predominantly African-American, with all four in communities with at least one-fourth of the population below the poverty line.

This finding prompted the United Church of Christ (UCC) to commission a national study on the relationship between race and siting of hazardous landfills. The UCC study (1987) compared the demographic characteristics of zip code areas without a waste treatment, storage or disposal facility (TSDF) to the characteristics of areas with such a facility. The results indicated that zip code areas without a TSDF were $12.3 \%$ minority. Zip code areas with one TSDF were $24 \%$ minority. Zip code areas with more than TSDF or having one of the nation's five largest landfills were 38\% minority. Further, the authors concluded that "three of every five Black and Hispanic Americans lived in communities with uncontrollable toxic waste sites" (United Church of Christ, 1987, p. 14).

These studies were important in three respects. First, the studies started a stream of empirical research that addressed environmental injustice claims. Second, the GAO and UCC findings proved critical in sharpening the rhetorical edge of environmental racism claims. Results showing a statistical correlation between race and incidence of environmental hazards resonated with an emergent environmental justice master frame. Third, the forceful infusion of racism into questions of inequity in hazardous waste dumping led to policies and 
corrective action thoroughly influenced by racialized politics rather than reforms informed singularly by class-based inequities.

Regarding this latter point, claims of environmental racism as the sole factor in hazardous waste siting decisions have not gone unchallenged. Alternative explanations for greater minority exposure to environmental hazards draw attention to the role of place of residence, class factors, and political participation. For example, Anderton, Anderson, Oakes and Fraser (1994, p. 229) found "no nationally and statistically significiant" effects for race in siting decisions. They suggested that what accounts for greater exposure of minorities to hazardous materials or undesirable land uses is that minorities are more likely to be employed in "dirty" industries which happen to be in close proximity to their places of residence. Others have pointed to market dynamics beyond race as an explanation whereby individuals with higher incomes can buy their way out of hazardous environments (Been, 1994a; Blais, 1996). Hamilton (1995) found that a community's ability to engage in collective action (modeled as voter turnout) against siting decisions was the best predictor of which communities were selected for planned expansions of commercial waste facilities. The confluence of race and class factors have been cited as well. As Been (1994a, p. 1421) suggested, siting decisions reflect the "complicated entanglement of class, race, educational attainment, occupational patterns, relationships between the metropolitan areas and rural or non-metropolitan cities." In view of these findings, some scholars take claims of environmental racism as weak and unsubstantiated (e.g., Blais, 1996) while others caution against fundamental modifications in environmental policy without more substantial evidence (Clark et al., 1995).

Finally, the 1991 First National People of Color Environmental Leadership Summit reflected the emergence and coalescence of an international and national network of grassroots organizers, academics and policymakers dedicated to protecting people of color communities from threats of pollution, hazardous waste sitings, and other unwanted land uses. Three important outcomes emerged from this summit. First, the term environmental justice supplanted environmental equity because justice was perceived as more inclusive and able to encompass equity, equality, and other related dimensions (Taylor, 2000). Second, the Summit marked a point where people of color insisted on "self-representation and speaking for themselves" rejecting a paternalistic partnership with mainstream environmental organizations (Di Chiro, 1996, p. 305). Third, the Summit's participants drafted a set of clearly articulated environmental justice principles. While originally drafted to serve as a framework for mobilization and political action, the principles have been shown to constitute "a well developed environmental ideological framework" or coherent "environmental justice paradigm" (Taylor, 2000, p. 538). As such, it stands as a significant contribution from people of color to ongoing discourse about human-environment relationships. Specifically, it renders a powerful critique upon colonial discourses of nature and European-American constructions of nature which form the ideological core of traditional natural resource management regimes (Cronon, 1996; Di Chiro, 1996; Taylor, 2000). Hence, ecological concern emanating from low-income and people of color communities has led some policymakers and scholars to consider how concepts such as biodiversity, sustainable development, and ecosystem management work to reproduce and perpetuate social inequalities (Guha, 1989; Neumann, 1998).

Moreover, there are signs that increasing attention is being given to issues of inequality in environmental amenities, parks, wilderness areas, and outdoor recreation areas (Aldy et al., 1999; Tarrant \& Cordell, 1999). Finally, as introduced earlier, the heightened visibility of environmental justice in public lands natural resources management also originates with a formal policy statement, Executive Order 12898 entitled "Federal Actions to Address Environmental Justice in Minority Populations and Low-Income Populations." Its scope 
encompasses all federal actions including public lands management and recreation and tourism. Public lands management decisions directly affect "one out of every three acres in the United States" while recreation use occurring on federal public lands represents approximately $40 \%$ of all recreation in the U.S. (Loomis, 1993, p. 18).

Thus, it is important to work through what environmental justice means in the context of recreation and tourism on public lands management. What is the state of the current literature on environmental justice in parks, forests, and other natural resource amenities, and what does it suggest? While recognizing that many activities and actions are involved in recreation management and tourism development, what are promising areas for improving our understanding of environmental justice in outdoor recreation? We $\mathrm{mm}$ to these questions in the remaining sections of the article.

\section{Outdoor Recreation Research and Environmental Justice}

Few studies have examined environmental justice or equity issues in terms of natural resource amenities, outdoor recreation, or tourism. With the exception of the investigations cited in this article, virtually no studies have examined empirically the spatial relationship (distributive) between peripheral groups-lower income and minority-to natural, outdoor recreation areas. There also has been no inquiry of procedural issues. Taylor (2000, p. 536), however, listed "the lack of access to or inadequate maintenance of environmental amenities like parks and playgrounds" in racial minority communities as environmental racism. Environmental justice in the area of natural resource availability would also include issues relating to violence and safety in recreation areas and pollution free environments.

Programs that fund various outdoor recreation resource development and service delivery, such as the Land and Water Conservation Fund (LWCF), the Sports Fishing Restoration and Wildlife Restoration programs, and the various subprograms and initiatives they support are also subject to critique. Under these programs, approximately one-half billion dollars are annually appropriated for land acquisition, park development, and fish and wildlife habitat improvements at the federal, state, and local levels. Salazar and Oliver (1998, p. 54) observed that equity considerations are "implicit" in decision making about prioritizing development projects and initiatives under such federally funded programs. Broadly then, in relation to outdoor recreation, environmental justice concerns focus on the possibility that policies and management actions will have consequences that are negative and disproportionate in impact on minority, low income, and other peripheral groups.

In assessing this issue, Aldy and colleagues (1999) asserted that natural resources such as parks and wilderness areas are societal goods like education and fair housing opportunities that ought to be distributed equitably, without regard to race or socioeconomic standing. They empirically assess environmental equity by testing the hypothesis that only the affluent benefit from preservation of Southern Appalachian spruce-fir forests. Using contingent valuation, the authors examine two regression models where willingness to pay (WTP) for protected forests was the dependent variable. The indicator variables included income and education along with age, gender, air environmental attitude variable, and distance from the location of spruce-firs. It was concluded that unique ecosystems such as those which contain Southern spruce-firs do not benefit only the well off, but are also valued by those with lower income levels.

Whitehead (2000) examined whether demand-side or supply-side factors led to differential demand for water quality. Demand-side factors referred to situations where communities with low land values recruit polluting industries for economic development or where demand for environmental quality among minorities is low relative to Whites. Supplyside factors are situations where polluting follows the path of least political resistance 
(e.g., Hamilton, 1995). In these situations, polluting industries gravitate toward communities that do not or cannot mount strong opposition. Based on a survey of eastern North Carolina households, Whitehead (2000) determined that there were statistically significant differences in average willingness to pay (WTP) for water quality improvement for White (\$345) and non-White respondents (\$132). Further, Whitehead decomposed the differential in WTP into differences due to socioeconomic characteristics or underlying structure of demand (i.e., tastes and preferences not measured by socioeconomic indicators) to determine what accounts for differences in demand for water quality. The difference due to demand structure was statistically significant.

Whitehead reasoned that recreationists tend to be the most likely beneficiaries of water quality, and participation rates in water-based recreation among non-Whites is low relative to Whites. Further, the author reported that White respondents were "significantly $(p=10)$ more concerned about water quality than non-White respondents" (p. 80). An implication of these findings is that observed differences in environmental quality outcomes are due to lower demand for environmental quality rather than deliberate targeting of vulnerable populations. However, in analyses of Black-White differences at the national level, racial and ethnic minorities express greater concern than Whites about the environment generally and about specific problems such as waste disposal, toxicity and nuclear hazards (Jones, 1998). As Whitehead (2000, p. 80) suggested, greater specification and origin of "taste and preferences" associated with variation in WTP for water quality are needed.

Tarrant and Cordell (1999) also empirically assessed environmental equity in terms of the spatial distribution of environmental amenities, in this case outdoor recreation sites. The objective of their study was to identify the socioeconomic composition of census block groups within 1,500 meters of the Chattahoochee National Forest in Georgia and to determine the spatial relationship between census block group characteristics. Using logistic regression, the location of recreation sites was modeled as a function of census block group characteristics (percent non-White, percent white-collar workers, percent local residents, and household income). Results showed income was the only independent variable with a significant relationship to the location of recreation sites. Campgrounds, wilderness areas, and desirable fishing areas were more likely to be proximal to census block groups with lower household incomes. In conclusion, the authors did not find evidence of environmental inequity in the distribution of outdoor recreation sites on the Chattahoochee National Forest. However, they cautioned that percent non-White may not have been significant because of the small proportion of minorities in the 18 -county area.

Whether racial and ethnic minorities are particularly vulnerable to risks associated with catching and consuming fish caught in contaminated waters has also been investigated. Fishing behavior is driven by multiple motives which may be tied to recreational and subsistence needs (Toth \& Brown, 1997) or deeply rooted in cultural traditions (Burger, 1999; Cornell, 1994). Researchers have found racial differences on two critical domains related to fishing on public lands: catch disposition and preferred species. Regarding catch disposition, West, Fly, Larkin and Marans (1992) found that Native Americans consumed $36 \%$ more of their catch and African-Americans 13\% more of their catch than Whites in the Detroit area. They noted the consumption patterns of minorities exceeded Michigan's standards for protecting citizens against exposure to toxins. In a study of South Carolina anglers on the Savannah River, Burger and others (1999) found that Blacks consumed significantly more fish per year than Whites, putting them at greater risk of exposure to radionuclides associated with the Department of Energy's Savannah River site.

Regarding species preference, West (1992) found that bottom feeders were most likely to be caught and consumed by low to moderate income minorities. Similarly, Heathwole and West (1985) found that minority anglers, particularly Hispanics, showed a greater 
tendency to keep bottom feeders for personal consumption. Catch disposition and species preference are significant because bottom feeders generally retain higher levels of toxins than migratory species or fish found in protected water systems in wilderness areas or wildlife refuges (Fossett et al., 1999). Related to this, there is a substantial body of research that suggests that the latter areas are more likely to be fished by Whites and individuals with moderate to high incomes (e.g., Bultena \& Field, 1978; Floyd, 1999; Gramann, 1996; Hendee, Stankey, \&Lucas, 1990; Washbume, 1978). Conversely, minorities and low income earners appear more likely to take their catch from inferior quality fisheries (Fossett et al., 1999). The need to consider racial differences in catch disposition, species preference and opportunity setting as they relate to health risks are clearly specified in the Environmental Justice executive order.

Salazar (1996) addressed equity in natural resources provision although their work does not include empirical tests. The author envisions a "people's forestry" that responds to the needs- of marginalized societal groups (p. 35). She argues that natural resource policies can be used to bring about social justice. The author acknowledges that resource management is political (i.e., decisions regarding outputs necessarily favor some groups); however, natural resource managers should use their power to ensure poor people and others who face social and economic challenges have the opportunity to enjoy forest amenities. This would require an application of environmental justice. The application of environmental justice to natural resource management involves three primary efforts: (a) natural resources ought be allocated through fair procedures (i.e., the interests of the poor as well as the affluent should be considered in resource allocation, (b) benefits and costs of resource management should be distributed fairly, and (c) citizens should have equal access to public resources.

It is important to note that the focus of these natural resource studies was distributive equity rather than procedural or corrective equity. Aldy et al. (1999), for example, tested whether benefits of Southern Appalachian spruce-fir forests accrue primarily to the affluent; Tarrant and Cordell (1999) examined the location of recreation resources with regard to lower income and minority communities; and, Whitehead (2000) tested for differential demand for environmental quality by race. Researchers investigating the threat of toxic exposure through fishing gave attention to whether minorities are more vulnerable because of "style" of fishing behavior and consumption; and Salazar (1996) discussed environmental justice in terms of the fair distribution of natural resources. Overall, these studies follow the lead of the first wave of environmental justice research, investigating distributive issues such as unequal outcomes. It will be important to understand environmental justice as a process, appropriately contextualized by social, historical, temporal, as well as spatial factors (Pellow, 2000; Pulido, 1996; Szasz \& Meuser, 1997). In short, how are unequal outcomes produced? What is the nature of differential outcomes in outdoor recreation? And, what social structural factors underlie differential access to resource allocation decisions? We address these and other research needs in the following section.

\section{Research Directions: $\Gamma$ ironmental Justice in Outdoor Recreation}

Growing policy and research concerns demand that attention be given to defining more specifically the nature of environmental justice in outdoor recreation. As stated, the environmental justice literature is built around analyses seeking to explain the disproportionate exposure of racial and ethnic minorities to environmental hazards. Few studies have proposed and examined environmental justice implications for provision of outdoor recreation and other natural resource amenities. In this section we propose three broad areas which we believe offer promise for improving understanding of these implications. We assume that benefits and costs associated with recreation allocation decisions can be conceptualized and analyzed similarly to those associated with the distribution of environmental hazards. 
First, there is a need to characterize the nature of environmental benefits and costs (or risk) in outdoor recreation and tourism. When the issue is placement of a hazardous waste storage, treatment or disposal facility in a community, the nature of benefits and risk is quite clear. Benefits and costs can be defined in terms of threats to human health. Analyses then focus on specific health indicators and whether and how they are correlated with minority status in terms of race/ethnicity or income. Despite the fact that there has been some conceptual work, it is not yet clear what constitutes an environmental risk or burden in outdoor recreation (Tarrant \& Cordell, 1999). For example, Driver and others (1991) proposed a model for evaluating positive and negative consequences of recreation resource allocation decisions. A basic assumption of their approach is that decision makers must know the good and bad impacts (i.e., benefits and costs) associated with their decisions. In their approach, impacts of allocation decisions can be specified by defining the benefits and costs of a change or proposed action. A benefit refers to a "change that is viewed to be advantageous-an improvement in condition, or gain to an individual, a group, to society, or to another entity" (p. 4). Conversely, costs (or losses) refer to changes viewed as disadvantageous resulting in a decline in condition. Economic benefits and costs refer to the monetary value associated with these changes. While cost-benefit analysis and economic efficiency approaches occupy substantial space in the literature, less is known about defining benefits and costs in noneconomic terms, such as "an improvement" or "decline" in condition (Driver et al., 1991). Advances along this line would have clear implications for environmental justice, particularly distributive justice. As Driver and Peterson (1986) suggested:

Results from the noneconomic measures are needed also to supplement the economic efficiency measures in public resource allocation decisions. Because of multiple public and private objectives, the efficiency measures are important but not sufficient (Randall 1984). Two equally efficient options can have very different distributional consequences, so it is important to expose how the gains and losses are divided up among the people. It is true also that two equally efficient options can produce very different kinds of beneficial consequences, irrespective of distributional differences. Most people would say that a hundred dollars worth of education is more valuable than a hundred dollars worth of candy (assuming equal public costs), though the economic efficiency criterion assigns them equal economic value (p. 5).

Following up on the Driver and others (199 1) framework, several research and demonstration projects have sought to define and specify recreation benefits in diverse recreation settings (e.g., Allen, Stevens, \& Harwell, 1996; Driver, 1996; Lee \& Driver, 1999; Stein, Anderson, \& Thompson, 1999). However the approach has not yet been extended to consider how recreation benefits are distributed across groups defined by race, ethnicity, or income. Opportunities for bridging benefits-based approaches and environmental justice indicators should be explored.

It will be important that efforts to define the nature of benefits and costs do not neglect definitions of individuals and groups negatively impacted by allocation decisions. An important feature of the environmental justice movement is the deconsttuction of environment as referent for nature in mainstream discourses (DeLuca, 1999; Di Chiro, 1996). The observations of Gibbs (quoted in DeLuca, 1999), former leader of the Love Canal Homeowners Association and founder of the Citizen's Clearinghouse for Hazardous Wastes, illustrate the way the meaning of environment has been altered. She observed: 
[o]ver the last ten years the Movement for Environmental Justice has redefined the word environment. No longer does the media, the general public or our opponents see the environmental movement as one that is focused on open spaces, trees and endangered species alone. They have finally got it! The Environmental Justice Movement is about people and the places they live, work, and play (p. 237).

It $i$ also evident among outdoor recreationists that how people of color define recreation settings has begun to challenge researchers' and agencies normative ideals regarding how natural areas should be experienced and managed (Gramann, Floyd, \& Ewert, 1991). Historically, public lands managers and researchers have prescribed the appropriate forms outdoor recreation behaviors should follow, through either management policies, or research in support of those policies, or both (Ewert, Gramann, \& Floyd, 1990). Broadly, for example, primitive and semiprimitive settings are typically viewed as best suited for ideal outdoor experiences. Similarly, over the last 30 years, low density settings and dispersed use have characterized outdoor recreation, especially wildland recreation. There is also the belief that outdoor recreation should be motivated by appropriate land ethics. These ideas have been supported by substantial investments in research and development programs focused on issues such as social carrying capacity, recreation opportunity spectrum planning, Limits of Acceptable Change, and other natural resource planning models. A significant number of researchers suggest that such ideals, inherent in these planning models, may not generalize across ethnic groups (e.g., Baas, Ewert, \& Chavez, 1993; Carr \& Williams, 1993; Gramann, Floyd, \& Saenz, 1993; Irwin, Gartner, \& Phelps, 1990; Lynch, 1993; Noe \& Snow, 1989/1990). Therefore, defining the goods and bads of recreation allocation decisions must recognize the environmental perspectives of diverse groups.

An additional point about the role of managers and researchers in defining environmental benefits and costs is worth noting. The environmental justice movement has tended to reject "technocratic rationality and top-down managerialism" in favor of "more democratic, locally and regionally based, decentralized" approaches to resources management (Di Chiro, 1996, p. 306). Also, within the environmental justice movement, people of color communities have tended to reject the absolute legitimacy of science as a way of characterizing their plight. As Capek (1993) observed in an environmental justice dispute in Texarkana, EPA scientists discounted the anecdotal, first-hand evidence of health problems associated with contamination, relying instead on statistics and technical information. She added that local residents "felt they were being talked down to by people who had many statistics but no answers and little common sense" (p. 14). Such sentiments underscore the need to contextualize definitions of recreation benefits and costs at the community level, giving careful attention to the way expert knowledge may be received.

A second research need is to characterize the nature of racial discrimination in recreation and tourism in relation to environmental justice. There is little guidance in the outdoor recreation literature on how to conceptualize this central claim of the environmental justice movement. Two competing perspectives in the broader environmental justice literature may offer some insight: (a) the pure discrimination model (e.g., Been, 1994b) and (b) the institution racism model (Bullard, 1996; Mohai \& Bryant, 1992). In order to document environmental discrimination under the pure discrimination model, it would be necessary to show that recreation allocation decisions have disproportionate negative impacts on minorities or low-income populations and that the impacts result from racist intent rather than incidental factors. Been's (1994b) research, for example, shows that while waste management facilities are more likely to be located in poor and minority neighborhoods, siting decisions may be based on "land prices, proximity to sources of waste, transportation networks, or other factors unrelated to race or poverty that nevertheless have an incidental, disproportionate effect upon people of color or the poor" (p. 17). 
Bullard (1996, p. 497), a primary proponent of the institutional racism model, on the other hand, argued that "[E]nvironmental racism refers to any policy, practice, or directive that differentially affects or disadvantages [whether intended or unintended] individuals, groups, or communities based on race or color" (italics in the original). Within this perspective, it is not necessary to reveal racist intent on the part of decision makers. Rather, environmental racism results from discrimination in other societal institutions. As summarized by Downey (1998):

environmental racism arises from factors such as racial discrimination in housing markets; the accumulation of disadvantages in various institutional settings that result in lower-than-average minority incomes; insufficient access to resources, information, and decision makers; and minority political powerlessness (p. 769).

Where the pure discrimination model would confine analyses of environmental or resource inequalities to documentation of racist motivations, the institutional racism model seeks to enlarge the scope of analysis to include social-historical and temporal contextual factors (Downey, 1998; Pellow, 2000). The latter is consistent with Pulido's (1996, p. 148) observation that environmental racism does not exist in a single form, composed of a "clearly demarcated set of actions." To address environmental justice in outdoor recreation fully, particularly claims of environmental racism, it will be necessary to recognize and deliberate on these kinds of issues.

Third, it will be important to consider the various dimensions (definitions) of environmental justice in future research. For example, initial environmental justice research in outdoor recreation (e.g., Tarrant \& Cordell, 1999) examined spatial and distributive issues, following the lead of early research on placement of hazardous facilities. Research of this kind is critical for establishing inequitable outcomes, documenting spatial relationships between unwanted or undesirable land uses and demographic groups. Analyses of the process that leads to unequal outcomes are also needed, because there may be situations which seem to exhibit equality of outcomes but in which the process favored some group(s) at the expense of others. Examining procedural justice along with distributive (or spatial) justice can provide a more complete representation of inequities in decision making.

From the standpoint of recreation on public lands, procedural justice will be a critical area for inquiry. Policy mandates such as the environmental justice executive order and directives require public participation. Historically, natural resource management agencies have obtained input primarily from traditional recreation stakeholders and their representatives (e.g., The Wilderness Society, Sierra Club, National Parks and Conservation Association, etc.) in their planning activities. Thus, the politics of outdoor recreation have been driven largely by white, middle-class interests (DeLuca, 1999; Taylor, 1999, 2000). The environmental justice movement, however, has impacted the stakeholder environment in which natural resource management agencies operate. In fact, of the 331 different environmental justice organizations listed in the People of Color Environmental Groups Directory (Bullard, 1994c), 114 deal with issues pertaining to wildlife and 131 deal with issues pertaining to parks and recreation (Taylor, 1999). Alliances formed between environmental justice organizations and mainstream environmental organizations such as the Sierra Club and the National Wildlife Federation represent another dimension of the changing political environment potentially affecting natural resource agencies (Longo, 1998). Identifying emerging stakeholders in order to ensure equitable access to information and decision making will be a major challenge for natural resource managers. How do such groups form? What barriers and constraints do nontraditional stakeholders encounter when attempting gain access to recreation allocation decision making processes? Under what conditions are coalitions 
between mainstream environmental organizations and people of color organizations most likely to form? How do managers distinguish between relevant and less relevant stakeholders? In other words, why might some claims and stakeholder relationships be regarded as legitimate and worthy of agency attention while others are not (Mitchell, Agle, \& Wood. 1997)? Confronting these kinds of questions has important implications in view of the composition and political orientation of environmental justice organizations. For example. Albrecht (1995) and Capek (1993) both observe that the environmental justice movement will represent peripheral groups that are likely to challenge perceived inequalities more vigorously than mainstream environmental organizations.

\section{Conclusions}

Environmental justice is a relatively new topic in the outdoor recreation literature. We attempted to highlight a few key issues with potential for further understanding of environmental justice issues in outdoor recreation. We provided some insight into the conditions surrounding the emergence of the environmental justice movement and its subsequent impact on natural resource management agencies. The movement has challenged prevailing modes of thinking about the relationship between human communities and nature or the environment. The environmental justice movement has also provided a strong critique of established resource management regimes. As a result, new forms of environmental political action merging grass-roots activities of local communities with national and international efforts came into being. For instance, new discourse and terminology such as "environmental justice" and "environmental racism" came into more frequent use. At this juncture, as environmental justice in outdoor recreation draws more research attention, it is appropriate to consider some basic research implications flowing from the continuing unfolding of this new social movement. We suggest that an important challenge to future research is a lack of clarity in definitions of environmental justice or lack of awareness of the different dimensions of environmental justice.

Resolution of this issue holds important implications for research and management actions. First, as discussed, the concepts of distributive justice and procedural justice direct research attention and policy responses along two different, but related tracks. Procedural justice may become even more imperative as the U.S. population continues to diversity along racial, ethnic, and cultural lines. Changing demographics (i.e., the immigration and migration of various racial, ethnic, religious, and cultural groups to and within the U.S. in recent decades) place added emphasis on the need to include new publics, many of whom enter American society at the margins and remain there to varying extents, in environmental decisions affecting community and leisure places, the workplace, and other natural areas. Such considerations will assume increased importance given the different ways in which various cultural groups interpret the environment (MacNaghten \& Uny, 1998) and concepts such as equity and justice.

Second, the nature of noneconomic environmental benefits, costs, and burdens in outdoor recreation is somewhat ambiguous. As noted, advances have been made in specifying the beneficial consequences of leisure involvement and in managing settings so as to produce benefits (e.g., Driver, 1996). Characterizing the nature of environmental costs or burdens resulting from recreation management decisions within an environmental justice context, however, has received limited treatment. As others have noted, the environmental justice movement has confronted natural resources management and social scientists alike with profound questions regarding fairness, equality, and justice. Attention to the kinds of issues discussed above will be important in framing appropriate research and managerial responses. To the extent that such basic issues are neglected, the core concerns of the environmental justice movement are likely to be overlooked in outdoor recreation research. 


\section{Notes}

1. Procedural and distributive justice and equity are used interchangeably.

2. Social equity is an umbrella term that encompasses procedural and geographical equity. If geographical and procedural equity exist, so does social equity. Social equity involves traditional sociological indicators such as race, ethnicity, class, and political power and how these influence environmental citing and regulatory decisions. An individual who is poor and or a member of a marginalized racial or ethnic group would have a greater chance than someone without these socioeconomic characteristics of being at greater risk of exposure to health threats and environmental hazards.

3. In Justice and the Politics of Difference (1990), Young criticizes a distributive model of social justice which privileges the allotment of material resources. For Young, this is a reductionist strategy that does not consider the political context in which decisions are made.

\section{References}

Albrecht, S. L. (1995). Equity and justice in environmental decision making: A proposed research agenda. Society and Natural Resources, 8, 67-72.

Aldy, J. L., Kramer, R. A., \& Holmes, T. P. (1999). Environmental equity and the conservation of unique ecosystems: An analysis of the distribution of benefits for protecting Southern Appalachian spruce-fir forests. Society \& Natural Resources, 12, 93-106.

Allen, L. R., Stevens, B., \& Harwell, R. (1996). Benefits-based management activity planning model for youth in at-risk environments. Journal of Recreation and Park Administration, 14, 10-19.

Anderton, D. L., Anderson, A. B., Oakes, J. M., \& Fraser, M. R. (1994). Environmental equity: The demographics of dumping. Demography, 31, 229-248.

Baas, J. M., Ewert, A., \& Chavez, D. J. (1993). Influence of ethnicity on recreation and natural environment use patterns: Managing recreation sites for ethnic and racial diversity. Environmental Management, 17, 523-529.

Been, V. (1994a). Locally undesirable land uses in minority neighborhoods: Disproportionate siting or market dynamic? Yale Law Journal, 103, 1383-1422.

Been, V. (1994b). Unpopular neighbors: Are dumps and landfills sited equitably? Resources, 115, 16-19.

Blais, L. E. (1996). Environmental racism reconsidered. North Catalina Law Review, 75, 75-15 1.

Bryant, B. (1995). Environmental justice: Issues, policies, and solutions. Washington, DC: Island Press.

Bullard, R. D. (1990). Dumping in Dixie: Race, class, and environmental quality. Boulder, CO: Westview Press.

Bullard, R. D. (1994a). Introduction. In R. Bullard (Ed.), Unequal protection: Environmental justice and communities of color (pp. xv-xxiii). San Francisco: Sierra Club Books.

Bullard, R. D. (1994b). Overcoming racism in environmental decisionmaking. Environment, 36, 1044.

Bullard, R. D. (1994c). People of color environmental groups directory. Flint, Ml: Mott Foundation.

Bullard, R. D. (1996). Environmental justice: It's more than waste facility siting. Social Science Quarterly, 77, 493-499.

Bullard, R. D., \& Wright, B. H. (1992). The quest for environmental equity: Mobilizing the African American community for social change. In R. Dunlap \& A. Mertig (Eds.), American environmentalism: The U.S. Environmental Movement 1970-1990 (pp. 39-49). New York: Taylor \& Francis.

Bultena, G. L., \& Field, D. R. (1978). Visitors to national parks: A test of the elitism argument. Leisure Sciences, 1, 395-4 10.

Burger, J. (1999). American Indians, hunting and fishing rates, risk and Idaho National Engineering and Environmental Laboratory. Environmental Research, 80, 319-329.

Burger, J., Stephens, Jr., W. L., Boring, C. S., Kuklinski, M., Gibbons, J. W., \& Gochfeld, M. (1999). Factors in exposure assessment: Ethnic and socioeconomic differences in fishing and consumption of fish caught along the Savannah River. Risk Analysis, 19, 427-438. 
Capek. S. M. (1993). The "environmental justice" frame: A conceptual discussion and an application. Social Problems, 40, 5-24.

Carr, D., \& Williams, D. R. (1993). Understanding the role of ethnicity in outdoor recreation experiences. Journal Leisure Research, 25, 22-38.

Clark, R. D., Lab, S. P., \& Stoddard, L. (1995). Environmental equity: A critique of the literature. Social Pathology, I, 253-269.

Cornell, G. L. (1994). Native American perceptions of the environment. In M. A. Lindquist \& M. Zanger (Eds.), Buried roots and indestructible seeds: The survival of American Indian life in story, history, and spirit (pp. 2 1-46). Madison, W: University of Wisconsin Press.

Cronon, W. (1996). The trouble with wilderness; or getting back to the wrong nature. In W. Cronon (Ed.), Uncommon ground: Rethinking the human place in nature (pp. 69-90). New York: W.W. Norton and Company.

Dawson, S. E. (1992). Navajo uranium workers and the effects of occupational illnesses: A case study. Human Organization, 51, 389-397.

DeLuca, K. (1999). In the shadow of whiteness: The consequences of constructions of nature in environmental politics. In T. K. Nakayama (Ed.), Whiteness: The construction of social identity (pp. 2 17-246). Thousand Oaks, CA: Sage Publications.

Di Chiro, G. (1992). Defining environmental justice: Women's voices and grassroots politics. Socialist Review, 22,93-l 30.

Di Chiro, G. (1996). Nature as community: The convergence of environment and social justice. In W. Cronon (Ed.), Uncommon ground: Rethinking the human place in nature (pp. 298-320). New York: W.W. Norton \& Company.

Downey, L. (1998). Environmental injustice: Is race or income a better predictor? Social Science Quarterly, 79, 766-778.

Driver, B. L. (1996). Benefits-driven management of natural areas. Natural Areas Journal, 16, 94-99.

Driver, B. L. Brown, P. J., \& Peterson, G. L. (1991). Benefits of Leisure. State College, PA: Venture Publishing.

Driver, B. L., \& Peterson, G. (1986). The values and benefits of outdoor recreation: An integrating literature review. In A literature review: The President's Commision on Americans Outdoors (pp. 1-9 Values Section). Washington, DC: U.S. Government Printing Office.

Ewert, A., \& Gramann, J. H., and Floyd, M. F. (1990). Ethnic patterns in recreational use of natural resources: Rethinking the marginality-ethnicity paradigm. Paper presented at the 1990 Rural Si ciological Society Meetings, August, Norfolk, VA.

Executive Order 12898, 3 C. F. R. 859 (1994).

Floyd, M. F. (1999). Race, ethnicity, and the National Park System. National Park Service Social Science Review, 1, 1-24.

Floyd, M. F., Gramann, J. H., \& Saenz, R. (1993). Ethnic factors and the use of public outdoor recreation areas: The case of Mexican Americans. Leisure Sciences, 15, 83-98.

Fossett, M., Kaiser, R., Matlock, M., Velditz, A., \& Woodard, R. (1999). Effluent trading: A policy review for Texas, A report of the center for public leadership studies. College Station, TX: Texas A \& M University, The Bush School of Government and Public Service.

Goldman, B. A. (1996). What is the future of environmental justice? Antipode, 2, 122-14 1.

Gramann, J. H. (1996). Ethnicity, race, and outdoor recreation: A review oftrends, policy, andresearch. (Miscellaneous Paper R-96-1). Vicksburg, MS: U.S. Army Engineer Waterways Experiment Station.

Gramann, J. H., Floyd, M. F., \& Ewert, A. (1991). Interpretation and Hispanic American ethnicity. In G. E. Machlis \& D. R. Field (Eds.), On interpretation: Sociologyfor interpreters of natural and cultural history (Rev. Ed.) (pp. 161-177). Corvallis, OR: Oregon State University Press.

Gramann, J. H., Floyd, M. F., \& Saenz, R. (1993). Outdoor recreation and Mexican-American ethnicity: A benefits perspective. In A. Ewert, D. Chavez, \& A. Magill (Eds.), Culture, conflict, and communication in the wildland-urban interface (pp. 69-84). Boulder, CO: Westview Press.

Guha, R. (1989). Radical American environmentalism and wilderness preservation: A third world critique. Environmental Ethics, I I, 71-83.

Hamilton, J. T. (1995). Testing for environmental racism: Prejudice, profits, political power? Joumal of Policy Analysis and Management, 14, 107-132. 
Heathwole, C., \& West, N. (1985). Shorefront fishing in York City. The Geographical Review, $75,245-264$.

Hendee, J. C., Stankey, G. H., \& Lucas, R. C. (1990). W ilderness management (Rev. Ed.). Golden, CO: North American Press.

Hofrichter, R. (1993). Toxic struggles: The theory andpractice of environmenruljusrice. Philadelphia: New Society Publishers.

Irwin, P., Gartner, W., \& Phelps, C. (1990). Mexican-American/Anglo cultural differences as recreation style determinants. Leisure Sciences, 12, 33.5-348.

Johnson, C. Y., Bowker. J. M., \& Cordell, H. K. (In press). Outdoor recreation constraints: An examination of race, gender, and rural dwelling. Southern Journal of Rural Sociology.

Johnson, C. Y., Bowker, J. M., English, D., \& Worthen, D. (1998). Wildland recreation in the rural south: An examination of marginality and ethnicity theory. Journal of Leisure Research, 30. 101-120.

Johnson, C. Y., Horan, P. M., \& Pepper, W. (1997). Race, rural residence, and wildland visitation: Examining the influence of sociocultural meaning. R ural Sociology, 62, 89-1 10.

Jones, R. E. (1998). Black concern for the environment: Myth versus reality. Society \& Natural Resources, I 1, 209-228.

Lake, R. W. (1996). Volunteer, NIMBYs, and environmental justice: Dilemmas of democratic practice. Antipode, 28, 160-I 74.

Lee, M. E., \& Driver, B. L. (1999). Benefits-based management: A new paradigm for managing amenity resources. In J. Aley, W. R. Burch, B. Conover, \& D. Field (Eds.), Ecosystem manage ment: Adaptive strategiesfor natural resources organizations in rhe 21st century (pp. 143-154). Philadelphia: Taylor \& Francis.

Longo, P. J. (1998). Environmental injustices and traditional environmental organizations: Potential for coalition building. In D. Camacho (Ed.), Environmental injustices, political struggles (pp. 165176). Durham, NC: Duke University Press.

Loomis, J. B. (1993). Inregrared public lands management: Principles and applications to national forests, parks, wildlife refuges, and $B L M$ lands. New York: Columbia University Press.

Lynch, B. D. (1993). The garden and the sea: U.S. Latino environmental discourses and mainstream environmentalism. Social Problems, 40, 108-124.

MacNaghten, P., \& Urry, J. (1998). Contested natures. London: Sage Publications.

McGurty, E. M. (2000). Warren County, NC, and the emergence of the Environmental Justice Movement: Unlikely coalitions and shared meanings in local collective action. Society and Natural Resources, 13, 373-387.

Mitchell, R. K., Agle, B. R., \& Wood, D. J. (1997). Toward a theory of stakeholder identification and salience: Defining the principle of who and what really counts. Academy of Management Review, 22, 853-886.

Mohai, P., \& Bryant, B. (1992). Environmental racism: Reviewing the evidence. In B. Bryant \& P. Mohai (Eds.), Race and the incidence of environmental hazards: A time for discourse (pp. 163176). Boulder, CO: Westview Press.

Neumann, R. P. (1998). Imposing wilderness: Struggles over livelihood and nature preservation in Africa. Berkeley, CA: University of California Press.

Noe, F. I?, \& Snow, R. (1989/1990). Hispanic cultural influence on environmental concern. Journal of Environmental Education, 21, 27-34.

Pellow, D. N. (2000). Environmental inequality formation: Toward a theory of environmental justice. American Behavioral Scientist, 43, 58 I-601.

Perrolle, J. A. (1993). Comments from the special issue editor: The emerging dialogue on environmental justice. Social Problems, 40, 1-4.

Pulido, L. (1996). A critical review of the methodology of environmental racism research. Anripode. $28,142-159$.

Randall, A. (1984). Budget cost analysis as an information system. In G. L. Peterson \& A. Randall (Eds.), Valuation of wildland resource benefits (pp. 65-75). Boulder: Westview Press.

Salazar, D. J. (1996). Environmental justice and a people's forestry. Journal of Forestry, 11, 32-36.

Salazar, D. J., \& Oliver, N. (1998). Environmental justice and natural resource management in the Pacific Northwest. Northwest Science, 72, 52-56. 
Satterfield, T. A. (2000). Risk, mediation and the stigma of a technological accident in an African American community. Human Ecology Review, 7, 1-1 1.

Stein, T. V., Anderson, D. H., \& Thompson, D. (1999). Identifying and managing for community benefits in Minnesota state parks. Journal of Recreation and Park Administration, 17, 1-19.

Szasz, A., \& Meuser, M. (1997). Environmental inequalities: Literature review and proposals for new directions in research and theory. Current Sociology, 45, 99-120.

Tarrant, M. A., \& Cordell, H. K. (1999). Environmental justice and the spatial distribution of outdoor recreation sites: An application of geographic information systems. Journal of Leisure Research, 31, 18-34.

Taylor, D. E. (1999). Mobilizing for environmental justice in communities of color: An emerging profile of people of color environmental groups. In J. Aley, W. R. Burch, B. Conover, \& D. Field (Eds.), Ecosystem management: Adaptive strategies for natural resource organizations in the 21 st century (pp. 33-67). Philadelphia: Taylor \& Francis.

Taylor, D. E. (2000). The rise of the environmental justice paradigm: Injustice framing and the social construction of environmental discourses. American Behavioral Scientist, 43, 508-580.

Toth, J. F., \& Brown, R. B. (1997). Racial and gender meanings of why people participate in recreational fishing. Leisure Sciences, 19, 129-146.

United Church of Christ, Commission on Racial Justice. (1987). Toxic waste and race in the United States: A national report on the racial and socioeconomic characteristics of communities surrounding hazardous waste sites. New York: United Church of Christ.

U.S. General Accounting Office (1983). Siting ofhazardous waste landfills and their correlation with racial and economic status of surrounding communities. GAO/RCED-83- 168. Washington, DC: U.S. Government Printing Office.

Warren, K. J. (1999). Environmental Justice: Some ecofeminist worries about a distributive model. Environmental Ethics, 21, $1.5 \quad 1-161$.

Washbume, R. F. (1978). Black under-participation in wildland recreation: Alternative explanations. Leisure Sciences, 1, 175-I 89.

West, P. C. (1989). Urban region parks and Black minorities: Subculture, marginality, and interracial relations in park use in the Detroit metropolitan area. Leisure Sciences, 11, 1 l-28.

West, P. C. (1992). Invitation to Poison? Detroit minorities and toxic fish consumption from the Detroit River. In B. Bryant \& I? Mohai (Eds.), Race and the incidence of environmental hazards: A time for discourse (pp. 96-99). Boulder, CO: Westview Press.

West, P. C., Fly, J. M., Larkin, F., \& Marans, R. W. (1992). Minority anglers and toxic fish consumption: Evidence from statewide survey of Michigan. In B. Bryant \& P. Mohai's (Eds.), Race and the incidence of environmental hazards: A time for discourse (pp. 100-I 13). Boulder: Westview Press.

Whitehead, J. C. (2000). Demand-side factors and environmental equity analysis. Society \& Natural Resources, 13, 75-81.

Wright, B. H. (1992). The effects of occupational injury, illness, and disease on the health status of Black Americans: A review. In B. Bryant \& P. Mohai (Eds.), Race and the incidence of environmental hazards: A rime for discourse (pp. 114-152). Boulder, CO: Westview Press.

Young, I. M. (1990). Justice and the politics of difference. Princeton, NJ: Princeton University Press. 